\title{
Analysis of Student Critical Thinking Ability in Colloid Chart with Problem-Based Learning Model
}

\author{
${ }^{1}$ Jefferson R Watulingas, ${ }^{2}$ Faul Samara \\ ${ }^{1,2}$ Department of Teacher Training and Education \\ ${ }^{1,2}$ Mulawarman University \\ Samarinda, Indonesia \\ ${ }^{1}$ jeffersonfkip.unmul@gmail.com \\ ${ }^{2}$ fauledane@gmail.com
}

\author{
${ }^{3}$ Medi Taruk \\ ${ }^{3}$ Department of Computer Science and IT \\ ${ }^{3}$ Mulawarman University \\ Samarinda, Indonesia \\ ${ }^{3}$ meditaruk@fkti.unmul.ac.id
}

\begin{abstract}
The ability to manage learning using a variety of methods, models and learning techniques is needed to improve teachers' knowledge and teaching skills. The ability to choose appropriate methods, models and learning techniques in the teaching and learning process will have an effect on the success of student learning. Problem-based learning model is a learning model that uses real-world problems as a context for learners to learn about thinking and problem-solving skills, and to acquire important knowledge of subject matter.
\end{abstract}

Keywords-Critical Thinking, colloid, Problem Based Learning.

\section{INTRODUCTION}

Education in schools is a planned process and has a purpose so that everything done by teachers and students directed to the achievement of learning objectives [1]. The planned educational process is directed to create a conducive learning atmosphere as well as a fun learning process. In education between process and learning outcomes must be run in balance. Learning and learning atmosphere is directed so that learners can develop their own potential, so that education should be student oriented (student active learning) and learners should be viewed as a developing and has potential [3].

The task of educators is to develop the potential of the child. This means the success or failure of the achievement of educational goals depends on how many learning processes experienced by students as students. However, the fact that the process of teaching and learning in schools tend to be monotonous, classical and not variatif, where the learning process like this that makes students less interested and eventually become bored. In addition there are still many teachers who only tend to move and provide as much information to the students, so that the dominance of teachers in the learning process causes students not much role and looks passive [2][4].

Based on the results of intensive study on the pattern of learning and understanding of students concluded that the learning process tends to text book oriented and not related to everyday life. One effort to solve the problem then it is necessary to use the method of learning that can increase attention, motivation, way of thinking and student learning outcomes on learning materials. Learning model that can be used is problem based learning (problem based learning). This research is to know the critical thinking ability of students with problem based learning model on colloidal subject of class XI IPA 2 SMA Negeri 11 Samarinda.

\section{LITERATURE REVIEW}

Teaching-learning is all deliberate in order to give students the possibility for a teaching-learning process in accordance with the stated objectives. The ultimate goal of the learning process is student learning. The teaching-learning process includes activities undertaken by teachers from planning, implementation of activities to evaluation, and follow-up programs that take place in educational situations to achieve learning. Based on some of these opinions, it can be said that the process of teaching and learning is an activity that interacts between teachers and students to achieve learning objectives [5][6].

Learning strategy is the general pattern of the actions of teachers and students in the realization of learning activities. The strategy in this case shows the abstract characteristics of a series of changes in teachers and students in a lesson. Teaching method is a tool that is part of the tools, tools and ways in the implementation of a learning strategy, because the learning strategy is a means and tools to achieve learning objectives, then the method of teaching is a tool to achieve learning objectives [6].

\section{A. Learning Objectives}

Learning is an activity undertaken by the teacher in such a way that student behavior changes to a better direction [20]. The form of teacher activity may be the provision of the environment, the provision of opportunity or the giving of material in such a way that the student can respond and think to recognize, understand, and organize it into a meaningful pattern [25].

Learning is an activity done consciously and deliberately, therefore learning must have a purpose. The purpose of learning is to help the students to gain experience and with that experience the student's behavior increases, both quantity and quality. Behavior in question includes knowledge, skills, and 
values or norms that serve as a controlling attitude and behavior of students [24][25].

\section{B. Characteristics of Learning}

The characteristics of learning are the characteristics or circumstances typical of the learning activities, thus the characteristics of this lesson will differentiate them from nonlearning activities. The characteristics of learning can be expressed as learning is done consciously and systematically planned, can foster the attention and motivation of students in learning, can provide interesting and challenging learning materials for students, can use learning aids that are appropriate and interesting, can create an atmosphere of learning which is safe and fun for students [29].

\section{Learning Model}

Learning model is a pattern that is used as a guide in planning the learning in the classroom or learning in the tutorial setting and to determine the learning tools including books, movies, computers and curriculum. The learning model refers to the learning approach including the learning objectives, the stages of the learning activities, the learning environment, and the management of the class. Based on the above definition can be concluded that the learning model is a conceptual framework that describes the systematic procedures in organizing learning experiences to achieve learning objectives that serve as teacher guidelines in designing and implementing learning activities. Manage the learning environment and manage the classroom [29].

\section{Problem Based Learning}

Learning based on the problem is the interaction between the stimulus and the response, is the relationship between the two directions of learning and the environment. The environment provides input to students in the form of help and problems, whereas the brain's nervous system effectively interprets the aid so that problems encountered can be investigated, assessed, analyzed, and searched for. Problembased teaching is an effective teaching in high-level thinking processes. This learning helps students to process the readymade information in their minds and develop their own knowledge of the social world and beyond [30].

Problems in Problem-based learning models are openended issues. This means that the answer to the problem is uncertain. Every student, even a teacher, can develop possible answers. The problem-based learning model provides an opportunity for students to explore collect and analyze the data completely to solve the problems encountered [29].

Problem-based learning model can be defined as a series of learning activities that emphasize the process of solving problems faced scientifically. The existence of stimulus or stimulus in the form of problems relating to the subject matter, the ability of students to analyze a problem based on appropriate theory will be able to give birth a new knowledge and new ways of dealing with various problems related to the subject matter learned [29][30].

\section{E. Colloid System}

Colloid system is a form of mixture that the situation lies between the solution and suspension (coarse mixture). Examples are glue, jelly, and coconut milk. The colloid name was given by Thomas Graham in 1861. One of the principles that distinguishes the form of one mixture with the other mixture is the size of the particle. Based on this, the mixture is divided into 3 common forms, namely suspension, colloid and solution [29].

Colloid is also called colloidal dispersion or colloidal suspension is a mixture between the true solution and the suspension. For example, fresh milk, which consists of fine grains of butter fat are dispersed in aqueous phases that also contain casein and some other substances. Examples of colloids such as milk, the solute particles are larger than the particles of the solution but smaller than the particles floating on the suspension. The shape of the colloidal particles is compared to the size of the medium in which the particles are, so the term dispersed and dispersing mediums are used [30].
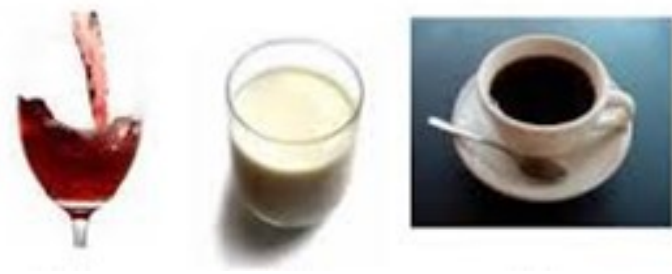

Fig. 1. Example Solution in Colloid

\section{RESEARCH METHOD}

The objectives of the research which has been established a systematic procedure is established. In general, research procedures can be divided into 3 stages, namely the preparation stage, the implementation stage and the completion stage.

\section{A. Data Collection Method}

In this case, the data was obtained through a test at the end of the meeting which contained indicators of critical thinking ability (Interpretation, Analysis, Evaluation, Inference, Explaining Ability, and Self-regulation). Problem test is given to determine students' critical thinking skills after following the lesson. Problem test made by researchers in essay form. This test is done individually.

\section{B. Data Analysis Method}

This research is descriptive qualitative, which means only describe the data obtained through the provision of questions as training and comprehension test learning. The data obtained are then compiled, explained and finally analyzed by describing or describing. In detail the analysis is used in 6 stages, namely:

- Provide a raw score for each student answer that refers to the assessment guidelines that have been made.

- Calculate the value that students get for each indicator of critical thinking ability of each meeting by using equation (1).

Equation (1)

$$
\text { Score }=\frac{\text { Score } 1}{\text { Maks Score }} \times 100
$$


- Determining the average student score for each indicator of critical thinking based on the value obtained by students at each meeting using equation (2). Equation (2) $\quad \overline{\mathrm{X}}_{\text {Score }}=\frac{\text { Score 1+Score } 2}{2}$

- Determine the ability category for each student for each critical thinking skill based on the capability category scale presented in Table I.

\section{TABLE I. CATEGORY ABILITY SCALE}

\begin{tabular}{|l|l|}
\hline Scores & $\begin{array}{l}\text { Level of Critical Thinking Ability and } \\
\text { Student Learning Outcomes }\end{array}$ \\
\hline $81 \leq X \leq 100$ & Very Good \\
\hline $61 \leq X \leq 80$ & Good \\
\hline $41 \leq X \leq 60$ & Not Bad \\
\hline $21 \leq X \leq 40$ & Bad \\
\hline $0 \leq X \leq 20$ & Very Bad \\
\hline
\end{tabular}

- Calculate the percentage of student distribution for each capability category in each critical thinking skill using equation (3).

Equation (3) student distribution (\%) $=\frac{\Sigma X}{\Sigma Y} \times 100 \%$

- Interpret the data of the obtained distribution using criteria as in Table II.

TABLE II. PERCENTAGE OF StUdENT Distribution

\begin{tabular}{|l|l|}
\hline Percentage $(\%)$ & Qualitative Interpretation \\
\hline 0 & Null \\
\hline $0 \leq X \leq 25$ & Fraction \\
\hline $26 \leq X \leq 49$ & Nearly Half \\
\hline 50 & Half \\
\hline $51 \leq X \leq 75$ & The most of \\
\hline $76 \leq X \leq 99$ & Almost entirely \\
\hline 100 & All \\
\hline
\end{tabular}

\section{RESUlts AND DisCUSSION}

The results of data analysis obtained from the research that has been done in the form of percentage value on each indicator of critical thinking ability is the ability of interpretation, analysis, evaluation, inference, ability to explain, and self-regulation students SMA Negeri 11 Samarinda Class XI IPA 2. The results presented in the form graph and table of percentage of students as a whole on each indicator of critical thinking ability.

TABLE III. SCORE VALUE FOR EACH INDICATOR OF OVERALL CRITICAL THINKING ABILITY OF STUDENTS

\begin{tabular}{|l|l|l|l|}
\hline \multirow{2}{*}{ No. } & \multirow{2}{|l|}{ Student Ability } \\
\cline { 3 - 4 } & Critical Thinking Indicators & $\begin{array}{l}\text { Average Grade } \\
\text { Students Overall } \\
\text { Capability }\end{array}$ & Category \\
\hline 1. & Interpretation & 66,50 & Good \\
\hline 2. & Analysis & 64,22 & Good \\
\hline 3. & Evaluation & 58 & Not Bad \\
\hline 4. & Inference & 53,43 & Not Bad \\
\hline 5. & Ability to Explain & 51,40 & Not Bad \\
\hline 6. & Self regulation & 59,27 & \\
\hline
\end{tabular}

This study aims to determine students' critical thinking skills consisting of the ability of interpretation, analysis, evaluation, inference, ability to explain, and self-regulation through the model of Problem Based Learning which is one model of learning as a series of learning activities that emphasizes the process of problem solving faced scientifically. The existence of stimulus or stimulus in the form of problems relating to the subject matter, the ability of students to analyze a problem based on appropriate theory will be able to give birth a new knowledge and new ways of dealing with various problems related to the subject matter learned. Learning process can train students' critical thinking ability because in the implementation the students are given the opportunity to learn to find and arrange the concept of each material being taught. Based on the results of tests that have been obtained, researchers can measure students' critical thinking skills for each indicator that exists. The description of the research results for each critical thinking indicator is presented in Figure 2.

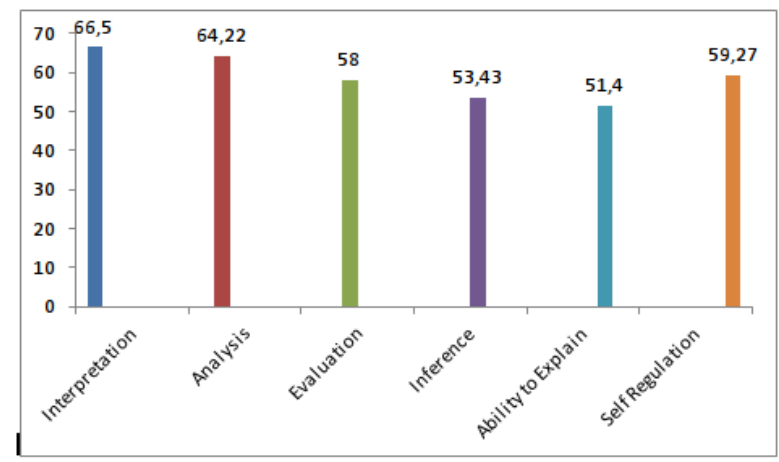

Fig. 2. Average Student Scores On Six Indicators

The average value of students' interpretation ability has the highest ability score among the six other indicators. The second rank is the average value of analytical skills, the third rank of self-regulation ability, the fourth rank of evaluation ability, the fifth ranking of inference capability, and the average value of explaining ability. The average value of explaining ability has the lowest ability score among the six indicators, this is because most students have a less obvious answer that gets only a half score and a lack of student attention when the teacher explains the material. The level of mastery of students on critical thinking skills obtained by category enough.

In each indicator of critical thinking ability, in working on the problems that most students have difficulty on the material properties of colloids. However, basically of the six critical thinking skills is strongly influenced by the ability of students that involves the ability to remember, understand, and analyze a problem. In the ability of interpretation and analysis quite good, but the ability of inference, evaluate, self-regulation and ability to explain need to be improved again.

Based on the results of research that has been done and that the advantages of the Problem Based Learning model of learning is from this research, among others:

- Students can improve their understanding of the material they have learned because the students themselves find the solution. 
- Students can feel the benefits of learning because the problems solved directly related to everyday life or real life so as to increase student motivation and interest in the material he studied.

- Can build good group collaboration and make students more independent, able to give opinions and accept opinions of others.

In addition to the advantages of the Problem Based Learning model based on the research that has been done there is also a weakness of the model of Problem Based Learning that students who have no interest or no understanding of the material learned then students will be reluctant to try to be able to solve the problem.

\section{CONCLUSION}

Based on the results of research and data analysis can be concluded that the average value of critical thinking ability of students of class XI IPA 2 SMA Negeri 11 Samarinda on colloidal subject through model of learning problem based learning as a whole on the interpretation ability of 66.50 including good category; analytical ability of 64,22 including good category; evaluation ability of 58 including enough category; the inference ability of 53.43 including enough category; ability to explain equal to 51,40 including enough category; and self-regulation ability of 59.27 with enough category.

\section{REFERENCES}

[1] Sarimanah, E and Efendi, R. 2017. Problem Based Model in Increasing Students Ability to Design Interactive Teaching Media. WALS.

[2] Fitriawati, N. 2010. Penerapan Model Pembelajaran Berbasis Masalah (Problem Based Learning) Dalam Meningkatkan Kemampuan Berpikir Kritis Siswa Pada Mata Pelajaran IPS Terpadu Kelas VIII di MTsN Selorejo Blitar. (http://Fitria.wordpress.com/2011/07/29/penerapanmodel-pembelajaran-berbasis-masalah-problem-based-learning/) diakses tanggal 26 Februari 2012.

[3] Hassoubah, Z. I. (2004). Developing Creatif and Critical Thinking Skill (Bambang Suryadi. Terjemahan). Bandung: Nuansa. Buku asli diterbitkan tahun 2002.

[4] Peter A. Facione. 2013. Critical Thinking: What it is and Why it Counts Facione \& Gittens, Pearson Education.

[5] Ratnaningsih, N. (2003). Pengembangan Kemampuan Berfikir Matematik Siswa SMU Melalui Pembelajaran Berbasis Masalah.

[6] Trianto. 2009. Mendesain Model Pembelajaran Inovatif-Progresif: Konsep, Landasan, dan Implementasinya pada Kurikulum Tingkat Satuan Pendidikan (KTSP). Jakarta: Kencana.

[7] Wina, S. 2009. Model Pembelajaran Berorientasi Standar Proses Pendidikan. Jakarta: Kencana.J. Clerk Maxwell, A Treatise on Electricity and Magnetism, 3rd ed., vol. 2. Oxford: Clarendon, 1892, pp.68-73.

[8] I.S. Jacobs and C.P. Bean, "Fine particles, thin films and exchange anisotropy," in Magnetism, vol. III, G.T. Rado and H. Suhl, Eds. New York: Academic, 1963, pp. 271-350.

[9] K. Elissa, "Title of paper if known," unpublished.

[10] R. Nicole, "Title of paper with only first word capitalized," J. Name Stand. Abbrev., in press.

[11] Y. Yorozu, M. Hirano, K. Oka, and Y. Tagawa, "Electron spectroscopy studies on magneto-optical media and plastic substrate interface," IEEE Transl. J. Magn. Japan, vol. 2, pp. 740-741, August 1987 [Digests 9th Annual Conf. Magnetics Japan, p. 301, 1982].

[12] M. Young, The Technical Writer's Handbook. Mill Valley, CA: University Science, 1989. 